\title{
ANALISIS PENGARUH KUALITAS PELAYANAN TERHADAP KEPUASAN KONSUMEN (PT. GAIDO CITO EKAKURINDO CABANG SURABAYA)
}

\author{
Alexie Julios Caesar, Suhartini \\ Jurusan Teknik Industri Institut Teknologi Adhi Tama Surabaya \\ Jalan Arief Rachman Hakim 100 Surabaya \\ ttitin63@yahoo.com
}

\begin{abstract}
ABSTRAK
Banyak faktor dalam menentukan kepuasan pelanggan salah satunya yaitu dengan menentukan presepsi pelanggan mengenai kualitas jasa yang berfokus pada lima dimensi kualitas jasa. Lima dimensi tersebut yaitu, Reliability, Responsiveness, Assurance, Emphaty dan tangible. Dengan banyaknya persaingan jasa pengiriman ini maka perlu menjaga kepuasan dan pelayanan yang baik terhadap pelanggan. Penelitian ini mengukur kepuasan pelanggan terhadap pelayanan jasa di PT.Gaido Cito Ekakurindo Cabang Surabaya dengan menghitung penilaian dari pelanggan terhadap tingkat kepentingan dan tingkat kinerja yang ada. Customer Satisfaction Index (CSI) digunakan untuk menganalisis tingkat kepuasan pelanggan secara keseluruhan tentang kualitas pelayanan. Sedangkan regresi linier digunakan untuk mengetahui besarnya pengaruh dari variabel independen (Tangibles, Reliability, Responsiveness, Assurance dan Emphaty) terhadap variabel dependen (kepuasaan pelanggan). Berdasarkan hasil anlisis yang telah dilakukan dengan menggunakan CSI menunjukan nilai 0,566 atau 56\% cukup puas dan hasil variabel yang sangat berpengaruh harus diperbaiki dari regresi menunjukan variabel tangible terdapat di kuadran 1 yang dapat diketahui dengan regresi dan Importance Performance Analisys (IPA).
\end{abstract}

Kata Kunci : Kepuasan Pelanggan, Regresi Linier Berganda, Importance Performance Analysis (IPA), Customer Satisfaction Index (CSI).

\section{PENDAhUluAN}

Adanya sebuah kebutuhan atau tuntutan dari konsumen yang semakin kompleks. Perkembangan industri jasa yang semakin besar yang didorong pula oleh kemajuan pesat dalam teknologi dan informasi. Dan untuk memenuhi tuntutan tersebut, pihak produsen dalam hal ini perusahaan harus mampu meningkatkan efektifitas dan efisiensi kerja, sebab jika tidak maka perusahaan tidak akan mampu bersaing dengan perusahaan lainnya dan oleh karena itu perusahaan bisa tertinggal.

PT.Gaido Cito Ekakurindo merupakan salah satu perusahaan jasa pengiriman barang yang berlokasi di Kutisari Utara VII No 19, Cabang Surabaya. Perusahaan ini melayani pengiriman barang produk maupun dalam bentuk dokumen dengan berbagai tujuan wilayah sekitar Surabaya.

PT.Gaido Cito Ekakurindo, mengingat pada bulan-bulan terakhir ini ada peningkatan komplain. Komplain Perkembangan industri jasa belakangan ini semakin pesat, hal ini merupakan yang sering terjadi yaitu keterlambatan waktu dalam pengiriman dan kerusakan produk, mengacu dari kondisi tersebut semakin banyaknya respon masyarakat Surabaya bahwa menunjukan banyaknya berbagai komplain terutama di sektor ketepatan waktu yang sering terjadi maka perusahaan harus lebih fokus dalam memberikan pelayanan yang berkualitas dan menjadi bagian dari solusi permasalahan pengiriman barang seperti produk yang semakin kompleks.

\section{TINJAUAN PUSTAKA}

\section{A. Kepuasan Pelanggan}

Kepuasan pelanggan atau konsumen berhubungan dengan mutu dari produk yang ditawarkan oleh merka. Kepuasaan konsumen mempunyai tingkat masing-masing tergantung apa yang mereka proleh, Disini akan diuraikan beberapa definisi kepuasan 
menurut diantaranya menurut Kotler dan keller (2007 hal 177) yang menyatakan bahwa: "Kepuasan adalah perasaan senang atau kecewa seseorang yang muncul setelah membandingkan kinerja (hasil) produk yang dipikirkan terhadap kinerja (atau hasil) yang diharapkan”. Menurut Sunarto (2006, hal 17) "Kepuasan pelanggan adalah perasaan senang atau kecewa seseorang yang muncul setelah membandingkan antara persepsi/kesannya terhadap kinerja suatu produk dan harapan-harapannya”. Menurut Yazid, (2005, hal 55) "Kepuasan adalah merupakan ketiadaan perbedaan antara harapan yang dimiliki dan unjuk kerjayang senyatanya”.

\section{B. Pengukuran Kepuasan Pelanggan}

Ada beberapa metode yang dapat digunakan setiap perusahaan untuk mengukur dan memantau kepuasan pelanggan dan pelanggan pesaing. Kotler dan Tjipto dan Chandra (2005) mengidentifikasi empat metode untuk mengukur kepuasan pelanggan, yaitu :

1. Sistem Keluhan dan Saran

2. Ghost Shopping (Mystery Shopping)

3. Lost Customer Analysis

4. Survei Kepuasan Pelanggan

\section{Uji Validitas dan Reliabilitas}

Pada tahap ini dilakukan pengujian terhadap kuisioner awal. Uji yang dilakukan adalah uji kecukupan data, uji validitas dan uji reliabilitas.

1. Uji validitas dilakukan untuk mengetahui apakah pertanyaan-pertanyaan dari kuisioner tersebut tepat sasaran atau tidak.

2. Uji reliabilitas dilakukan untuk mengetahui tingkat konsistensi akan konsumen terhadap pertanyaan yang ada, jadi apakah data yang diperoleh akan memberikan hasil yang sama atau tidak.

\section{Customer Satisfaction Index}

Menurut Rangkuti (2002) dalam Ardhika (2007), pengukuran terhadap Cnstorner Satisfaction Index (CSI) diperlukan untuk mengetahui tingkat kepuasan responden secara menyeluruh dengan melihat tingkat kepentingan dari atribut atribut roduk atau jasa tersebut. Bisa digunakan untuk membandingkan tingkat kepuasan dua produk/lebih, maupun melihat perkembangan tingkat kepuasan konsumen akan sebuah produk dari waktu ke waktu (time series).

\section{Menghitung Weighting Factors (WF)}

Yaitu fungsi dari media importance score atau skor median tingkat kepentingan masing-masing atribut dalam bentuk 5\% dari total median importance score atau skor median tingkat kepentingan untuk seluruh kriteria atau atribut yang diuji.

\section{Menghitung Weighted Score (WS)}

Yaitu fungsi dari median satisfaction score atau skor median tingkat kepuasan masing-masing atribut dikalikan dengan Weighting Factors (WF) masing-masing atribut.

\section{3. $\quad$ Menghitung Weighted Median Total (WMT)}

Yaitu total dari nilai Weighted Score (WS) dihitung secara keseluruhan.

\section{Customer satisfaction index}

Yaitu perhitungan dari Weighted Median Total (WMT) dibagi skala maksimum atau hightest scale dikali 100\%. Tingkat kepuasan responden secara menyeluruh dapat dilihat dari kriteria tingkat kepuasan pelanggan atau konsumen, dengan kriteria sebagai berikut :
a. $0.81-1.00$ : Sangat Puas
b. $0.66-0.80$ : Puas
c. $0.51-0.65$ : Cukup Puas 
d. $0.35-0.50$ : Kurang Puas

e. $0.00-0.34$ : Tidak Puas

\section{E. Importance Performance Analisys (IPA)}

Menurut Supranto (1997) Importance Performance Analisys adalah suatu metode untuk menganalisis sejauhmana tingkat kepuasan seseorang terhadap kinerja sebuah perusahaan. Didasarkan hasil penelitian tingkat kepentingan dan hasil penilai kinerja, akan dihasilkan suatu perhitungan mengenai tingkat kesesuaian antara kepentingan dan tingkat pelaksanaanya pada sebuah perusahaan.

Menurut J. Supranto (1997), sumbu mendatar (X) dalam diagram kartesius memuat nilai rata-rata skor kepuasan (performance), sedangkan sumbu tegak (Y) memuat nilai rata-rata skor kepentingan (importance), yang dirumuskan sebagai berikut:

Keterangan:

$$
T k i=\frac{\mathrm{X} \mathrm{i}}{\mathrm{Yi}} \times 100 \%
$$

Tki : Tingkat kesesuaian pelanggan

$\mathrm{Xi} \quad$ : Skor penilaian kepuasan kinerja pelayanan

Yi : Skor penilaian kepentingan pelanggan

Tingkat kesesuaian adalah hasil perbandingan skor kinerja dengan skor kepentingan pelanggan. Diagram kartesius sangat diperlukan dalam penjabaran unsurunsur tingkat kesesuaian kepentingan dan kinerja atau kepuasan pelanggan atas bagan yang terdiri dari empat bagian yang dibatasi oleh dua garis yang berpotongan tegak lurus pada titik - titik ( $\mathrm{X}, \mathrm{Y}$ ).

Rumus untuk menentukan setiap faktor yang mempengaruhi kepuasan pelanggan adalah :

Keterangan:

$$
\begin{aligned}
& X \mathrm{i}=\frac{\sum \mathrm{Xi}}{\mathrm{N}} \\
& Y \mathrm{i}=\frac{\sum \mathrm{Yi}}{\mathrm{N}}
\end{aligned}
$$

$\mathrm{Xi}=$ Skor rataan tingkat kinerja

$\mathrm{Yi}=$ Skor rataan tingkat harapan / kepentingan

$\mathrm{N}=$ Jumlah responden

Rumus yang digunakan untuk menjabarkan diagram kartesius adalah :

Keterangan

$$
\begin{gathered}
X 1=\frac{\sum_{i}^{n}=1 X i}{\mathrm{~K}} \\
Y 1=\frac{\sum_{i}^{n}=1 Y i}{\mathrm{~K}}
\end{gathered}
$$

$\mathrm{X} 1$ = Rataan skor tingkat kinerja seluruh atribut

Y1 = Rataan skor tingkat kepentingan/ harapan seluruh atribut

$\mathrm{K}=$ Banyaknya atribut yang mempengaruhi kepuasan pelanggan

Selanjutnya tingkat unsur-unsur tersebut akan dijabarkan dan dibagi menjadi empat bagian dalam diagram kartesius sebagai berikut : 
Tingkat Kepentingan

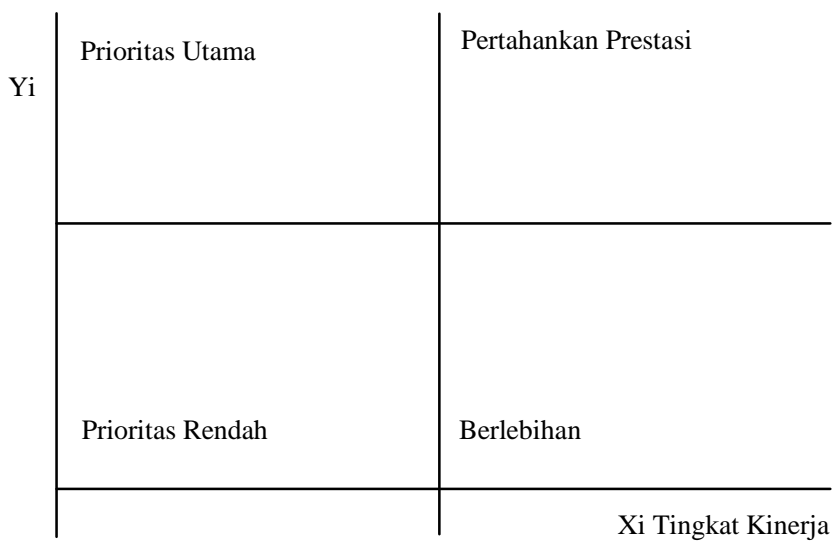

Gambar 1. Pembagian Kuadran Importance Performance Analisys

(Sumber : Rangkuti, 2003)

1. Kuadran 1 (Atrributes to improve)

Merupakan wilayah yang memuat faktor-faktor yang dianggap penting oleh penghuni namun pada kenyataannya belum sesuai seperti yang diharapkan (kepuasan yang diperoleh masih sangat rendah). Atribut-atribut yang masuk dalam kuadran ini harus ditingkatkan.

2. Kuadran 2 (Maintain Performance)

Merupakan wilayah yang memuat faktor-faktor yang dianggap penting oleh penghuni dan sudah sesuai dengan yang dirasakan sehingga tingkat kepuasannya relatif lebih tinggi. Karenanya atribut-atribut yang masuk dalam kuadran ini harus dipertahankan.

3. Kuadran 3 (Attributes to Maintain)

Merupakan wilayah yang memuat faktor-faktor yang dianggap kurang penting oleh penghuni dan pada kenyataannya, kinerjanya tidak terlalu istimewa.

4. Kuadran 4 (Attributes to De-emphasize)

Merupakan wilayah yang memuat faktor-faktor yang dianggap kurang penting oleh penghuni dan dirasakan terlalu berlebihan dalam kinerja pelayanannya.

\section{F. Analisis Regresi Linier Berganda}

Analisis ini digunakan untuk mengetahui besarnya pengaruh dari variabel independen (Tangibles, Reliability, Responsiveness, Assurance dan Emphaty) terhadap variabel dependen (kepuasaan pelanggan). Dan berikut grafik dari regresi linier dan regresi non linier

Keterangan :

$$
\mathrm{Y}=\mathrm{a}+\mathrm{b}_{1} \mathrm{x}_{1}+\mathrm{b}_{2} \mathrm{x}_{2}+\mathrm{b}_{3} \mathrm{x}_{3}+\mathrm{b}_{4} \mathrm{x}_{4}
$$

$$
\begin{aligned}
& \mathrm{Y}=\text { kepuasan pelanggan } \\
& \mathrm{a}=\text { variabel intersept } \\
& \mathrm{x}_{1}=\text { Tangibles } \\
& \mathrm{x}_{2}=\text { Reliability } \\
& \mathrm{x}_{3}=\text { Responsiveness } \\
& \mathrm{x}_{4}=\text { Assurance } \\
& \mathrm{x}_{5}=\text { Emphaty }
\end{aligned}
$$

$\mathrm{b}_{1}=$ variable tangibles

$\mathrm{b}_{2}=$ variable reliability

$\mathrm{b}_{3}=$ variable responsiveness

$\mathrm{b}_{4}=$ variable assurance

$b_{5}=$ variable emphaty 
1. Analisis $\mathrm{t}-$ test

$$
t=\frac{r s}{s / \sqrt{S x X}}
$$

Keterangan :

$$
\begin{aligned}
& \mathrm{t}=\text { nilai } \mathrm{t} \text { hitung } \\
& \mathrm{s}=\text { standard error } \\
& \mathrm{rs}=\text { korelasi variable } \\
& \text { Sxx = standard error regresi } \mathrm{xx}
\end{aligned}
$$

2. Analisis F test:

$$
\mathrm{F}=\frac{\mathrm{R}^{2}(\mathrm{k}-1)}{\left(1-\mathrm{R}^{2}\right) / N-k}
$$

Keterangan :

$\mathrm{R}^{2}=$ koefisien determinasi

$\mathrm{N} \quad=$ banyaknya sampel

$\mathrm{k} \quad=$ Banyaknya prediktor, yaitu $\mathrm{X}_{1}, \mathrm{X}_{2}, \mathrm{X}_{3}$ dan $\mathrm{X}_{4}$.

3. Koefisien determinasi

$$
\mathrm{R}^{2}=\frac{\mathrm{b}_{1}\left(\Sigma \Sigma_{1} \mathrm{Y}\right)+\mathrm{b}_{2}\left(\Sigma \Sigma_{2} \mathrm{Y}\right)+\mathrm{b}_{3}\left(\Sigma \Sigma_{3} \mathrm{Y}\right)}{\Sigma \mathrm{Y}^{2}}
$$

Dimana :

$$
\begin{array}{lll}
\mathrm{R}^{2} & =\text { koefisien determinasi } & \mathrm{X} 2=\text { variabel reliability } \\
\mathrm{Y} & =\text { variabel kepuasaan pelanggan } & \mathrm{X} 3=\text { variable responsiveness } \\
\mathrm{X}_{1} \quad \text { = variabel tangibles } &
\end{array}
$$

4. Analisis korelasi

$$
r=\frac{n \Sigma X Y-(\Sigma X) \cdot\left(\sum Y\right)}{\sqrt{\left\{n \Sigma X^{2}-(\Sigma X)^{2}\right\}\left\{\left[n \Sigma Y^{2}-(\Sigma Y)^{2}\right\}\right.}}
$$

Dimana:

$\mathrm{r}=$ hasil korelasi

$\mathrm{n}$ = banyaknya sampel

$\sum \mathrm{x}=$ total variable $\mathrm{x}$

$\sum \mathrm{y}=$ total variable $\mathrm{y}$

\section{METODE PENELITIAN}

Adapun tahap-tahap penelitian yaitu tahap persiapan, identifikasi masalah, menentukan tujuan, manfaat dan batasan, studi literatur dan study lapangan, tahap pengumpulan dan pengolahan data, pengumpulan data, penyusunan dan penyebaran kuisoner, uji validitas dan uji reliabilitas, penentuan jumlah sampel, pengolahan data, tahap analisis dan kesimpulan, tahap analisis dan interpretasi, kesimpulan dan saran.

\section{HASIL DAN PEMBAHASAN}

Pelanggan memiliki harapan terhadap kualitas pelayanan yang telah diberikan oleh PT. Gaido Cito Ekakurindo Cabang Surabaya. Berikut merupakan hasi pengolahan data berdasarkan dari penyebaran kuisioner terhadap 60 pelanggan PT. Gaido Cito Ekakurindo Cabang Surabaya dapat dilihat pada tabel 1. 
Tabel 1. Rata-rata Penilaian Tingkat Kinerja Terhadap Pelanggan PT. Gaido Cito Ekakurindo Cabang Surabaya

\begin{tabular}{|c|c|c|}
\hline No & Kriteria & Rata-rata \\
\hline \multicolumn{3}{|c|}{ Reliability } \\
\hline 1 & $\begin{array}{l}\text { Sejauh manakah PT. Gaido Cito Ekakurindo cabang Surabaya dapat } \\
\text { menjamin tidak terjadinya kesalahan dalam memberikan pelayanan yang } \\
\text { menyebabkan kerugian pelanggan }\end{array}$ & 2.85 \\
\hline 2 & Kemampuan pengiriman barang yang tepat waktu dan aman & 2.70 \\
\hline 3 & Biaya pengiriman yang sesuai dengan kualitas pelayanan yang diterima & 2.63 \\
\hline 4 & Kemampuan menjaga paket yang dikirim dalam keadaan utuh & 2.80 \\
\hline \multicolumn{3}{|c|}{ Responsiveness } \\
\hline 5 & Petugas cepat merespon keluhan pelanggan & 2.88 \\
\hline 6 & Petugas menunjukkan sikap ramah dan siap melayani pelanggan & 2.60 \\
\hline 7 & Kemampuan mendengarkan ketika pelanggan meminta pelayanan & 2.63 \\
\hline \multicolumn{3}{|c|}{ Assurance } \\
\hline 8 & $\begin{array}{l}\text { Jaminan ganti rugi oleh perusahaan terhadap kiriman yang hilang atau } \\
\text { rusak }\end{array}$ & 2.57 \\
\hline 9 & Bertanggung jawab terhadap keterlambatan pengiriman. & 3.23 \\
\hline 10 & $\begin{array}{l}\text { Petugas selalu menunjukkan sikap percaya diri dan siap melayani } \\
\text { pelanggan }\end{array}$ & 2.77 \\
\hline 11 & Petugas kurir menunjukkan sikap yang baik atau ramah & 2.92 \\
\hline \multicolumn{3}{|c|}{ Emphaty } \\
\hline 12 & $\begin{array}{l}\text { Kemampuan petugas helper PT. Gaido Cito Ekakurindo Cabang Surabaya } \\
\text { dalam memberikan pelayanan (mengangkat barang) }\end{array}$ & 2.98 \\
\hline 13 & Keramahan karyawan PT. Gaido Cito Ekakurindo Cabang Surabaya & 2.82 \\
\hline 14 & Pemberian informasi jika terdapat jenis pengiriman dan fasilitas baru. & 3.20 \\
\hline 15 & Berusaha mengenal pelanggan dan memahami kebutuhan mereka. & 2.87 \\
\hline \multicolumn{3}{|c|}{ Tangibles } \\
\hline 16. & Ketersediaan layanan selama 24 jam & 3.10 \\
\hline 17 & Penampilan karyawan PT. Gaido Cito Ekakurindo Cabang Surabaya & 2.73 \\
\hline 18. & Kebersihan dan keterampilan PT. Gaido Cito Ekakurindo Cabang Surabaya & 2.67 \\
\hline
\end{tabular}

\section{Rata-rata Penilaian Tingkat Kepentingan Pelayanan PT. Gaido Cito Ekakurindo}

Rata-rata penilaian tingkat kepentingan pelayanan PT.Gaido Cito Ekakurindo Cabang Surabaya berdasarkan penyebaran kuisioner 60 responden PT.Gaido Cito Ekakurindo Cabang Surabaya.

Tabel 2. Rata-rata Penilaian Tingkat Kepentingan Pelayanan PT. Gaido Cito Ekakurindo Cabang Surabaya

\begin{tabular}{|c|l|c|}
\hline No & \multicolumn{1}{|c|}{ HARAPAN ANDA } & \multicolumn{1}{|c|}{$\begin{array}{c}\text { Rata- } \\
\text { rata }\end{array}$} \\
\hline 1 & $\begin{array}{l}\text { Lokasi PT. Gaido Cito Ekakurindo Cabang Surabaya yang mudah di } \\
\text { jangkau }\end{array}$ & 2.77 \\
\hline 2 & $\begin{array}{l}\text { PT. Gaido Cito Ekakurindo Cabang Surabaya mempunyai kemampuan } \\
\text { pengiriman barang yang tepat waktu dan aman }\end{array}$ & 2.78 \\
\hline 3 & $\begin{array}{l}\text { Biaya pengiriman PT. Gaido Cito Ekakurindo Cabang Surabaya yang } \\
\text { sesuai dengan kualitas pelayanan yang diterima }\end{array}$ & 2.85 \\
\hline 4 & $\begin{array}{l}\text { PT. Gaido Cito Ekakurindo Cabang Surabaya menjaga paket yang dikirim } \\
\text { dalam keadaan utuh }\end{array}$ & 2.85 \\
\hline 5 & Kemampuan PT. Gaido Cito Ekakurindo menangani complain & 2.78 \\
\hline 6 & Kecepatan dan ketanggapan karyawan dalam pengurusan komplain dari & 3.02 \\
\hline
\end{tabular}




\begin{tabular}{|c|l|l|}
\hline & pelanggan jika ada paket terlambat, rusak atau hilang & \\
\hline 7 & Kemampuan mendengarkan ketika pelanggan meminta pelayanan & 3.03 \\
\hline 8 & $\begin{array}{l}\text { Jaminan ganti rugi oleh perusahaan terhadap kiriman yang hilang atau } \\
\text { rusak }\end{array}$ & 2.78 \\
\hline 9 & $\begin{array}{l}\text { PT. Gaido Cito Ekakurindo Cabang Surabaya bertanggung jawab terhadap } \\
\text { keterlambatan pengiriman. }\end{array}$ & 2.85 \\
\hline 10 & Kemampuan petugas CS dalam memberikan informasi yang dibutuhkan. & 2.97 \\
\hline 11 & petugas CS mencatat keluhan atau permintaan dengan benar & 2.88 \\
\hline 12 & $\begin{array}{l}\text { Kemampuan petugas helper PT. Gaido Cito Ekakurindo dalam } \\
\text { memberikan pelayanan (mengangkat barang) }\end{array}$ & 2.83 \\
\hline 13 & Keramahan karyawan PT. Gaido Cito Ekakurindo & 2.80 \\
\hline 14 & Pemberian informasi jika terdapat jenis pengiriman dan fasilitas baru. & 3.13 \\
\hline 15 & Berusaha mengenal pelanggan dan memahami kebutuhan mereka. & 3.05 \\
\hline 16 & Kelengakapan fasilitas penunjang (alat angkut, toilet, parker, dll) & 2.85 \\
\hline 17 & penampilan karyawan PT. Gaido Cito Ekakurindo & 2.93 \\
\hline 18 & $\begin{array}{l}\text { Tingkat kemudahan untuk melaporkan keluhan terhadap PT. Gaido Cito } \\
\text { Ekakurindo }\end{array}$ & 2.83 \\
\hline
\end{tabular}

Tabel 3. Rata-rata Penilaian Perceived Tingkat Kepentingan Pelayanan PT. Gaido Cito Ekakurindo Cabang Surabaya (lanjutan)

\begin{tabular}{|c|l|c|}
\hline 1 & $\begin{array}{l}\text { PT. Gaido Cito Ekakurindo Cabang Surabaya ini ramah dalam melayani } \\
\text { pelanggan }\end{array}$ & 3.07 \\
\hline 2 & $\begin{array}{l}\text { PT. Gaido Cito Ekakurindo Cabang Surabaya ini cepat dalam memberikan } \\
\text { pelayanan terhadap pelanggan }\end{array}$ & 3.00 \\
\hline 3 & PT. Gaido Cito Eakurindo ini tulus dalam melayani pelanggan & 2.98 \\
\hline 4 & $\begin{array}{l}\text { PT. Gaido Cito Ekakurindo Cabang Surabaya ini respon terhadap } \\
\text { permintaan pelanggan }\end{array}$ & 3.25 \\
\hline 5 & $\begin{array}{l}\text { Kebersihan, kerapihan dan kenyamanan ruang PT. Gaido Cito Ekakurindo } \\
\text { ini memberikan kenyamanan }\end{array}$ & 3.03 \\
\hline 6 & Lapangan parkir di PT. Gaido Cito Ekakurindo ini telah memadai \\
\hline 7 & $\begin{array}{l}\text { Kemampuan PT. Gido Cito Ekakurindo cepat dalam menangani proses } \\
\text { pengiriman }\end{array}$ & 3.17 \\
\hline 8 & $\begin{array}{l}\text { PT. Gido Cito Ekakurindo memberikan pelayananyang sesuai dengan } \\
\text { permintaan }\end{array}$ & 3.32 \\
\hline 9 & $\begin{array}{l}\text { Apakah di PT. Gaido Cito Ekakurindo menyediakan fasilitas yang } \\
\text { memadai }\end{array}$ & 3.07 \\
\hline 10 & $\begin{array}{l}\text { Apakah PT. Gaido Cito Ekakurindo cepat dan tanggap dalam memberikan } \\
\text { informasi yang dibutuhkan pelanggan }\end{array}$ & 3.40 \\
\hline 11 & Memberikan pemahaman dan penjelasan yang benar pada pelanggan \\
\hline 12 & Karyawan memahami secara spesifik pada saat pelanggan membutuhkan \\
\hline 13 & Karyawan membantu pelanggan yang membutuhkan secara tuntas & 3.25 \\
\hline 14 & $\begin{array}{l}\text { Memberikan penjelasan dengan menggunakan bahasa yang dipahami oleh } \\
\text { pelanggan }\end{array}$ & 3.27 \\
\hline 15 & $\begin{array}{l}\text { Karyawan PT. Gaido Cito Ekakurido memberikan pelayanan terbaik pada } \\
\text { pelanggan }\end{array}$ & 3.40 \\
\hline 16 & $\begin{array}{l}\text { Kesopanan karyawan PT. Gaido Cito Ekakurindo dalam memeberikan } \\
\text { pelayanan dalam pelanggan }\end{array}$ \\
\hline 17 & $\begin{array}{l}\text { PT. Gaido Cito Ekakurindo harus memperhatikan proses pengiriman } \\
\text { barang dari awal hingga akhir }\end{array}$ & 3.30 \\
\hline 18 & $\begin{array}{l}\text { Ketelitian dalam memeriksa kelengkapan dokumen dalam pengirirman } \\
\text { barang }\end{array}$ & 3.40 \\
\hline
\end{tabular}




\section{Customer Satisfaction Index (CSI)}

Pengukuran CSI ini dilakukan untuk mengetahui tingkat kepuasan pelanggan dan dijadikan sebagai acuan dalam menentukan sasaran yang akan datang. Hasil perhitungan CSI dapat dilihat pada tabel di bawah ini.

Tabel 4. Hasil Perhitungan Customer Satisfaction Index (CSI)

\begin{tabular}{|c|c|c|c|c|}
\hline & $\begin{array}{c}\text { Kepentingan } \\
(y)\end{array}$ & Factor (WF) & $\begin{array}{c}\text { Kinerja } \\
(\mathrm{x})\end{array}$ & Score \\
\hline Kriteria & $\begin{array}{l}\text { Rataan Tingkat } \\
\text { Kepentingan (y) }\end{array}$ & $\begin{array}{c}\text { Importance } \\
\text { Weigthing Factor } \\
\text { (WF) }\end{array}$ & $\begin{array}{c}\text { Rataan } \\
\text { Tingkat } \\
\text { Kinerja (x) }\end{array}$ & $\begin{array}{l}\text { Weighted } \\
\text { Score }\end{array}$ \\
\hline 1 & 2.92 & 0.054 & 2.85 & 0.15 \\
\hline 2 & 2.89 & 0.054 & 2.70 & 0.15 \\
\hline 3 & 2.92 & 0.054 & 2.63 & 0.14 \\
\hline 4 & 3.05 & 0.055 & 2.80 & 0.15 \\
\hline 5 & 2.91 & 0.054 & 2.88 & 0.16 \\
\hline 6 & 3.10 & 0.057 & 2.60 & 0.15 \\
\hline 7 & 3.18 & 0.059 & 2.63 & 0.16 \\
\hline 8 & 2.93 & 0.054 & 2.57 & 0.14 \\
\hline 9 & 3.13 & 0.055 & 3.23 & 0.18 \\
\hline 10 & 3.11 & 0.058 & 2.77 & 0.16 \\
\hline 11 & 3.09 & 0.057 & 2.92 & 0.17 \\
\hline 12 & 3.05 & 0.057 & 2.98 & 0.17 \\
\hline 13 & 3.10 & 0.057 & 2.82 & 0.16 \\
\hline 14 & 3.18 & 0.059 & 3.20 & 0.19 \\
\hline 15 & 3.18 & 0.057 & 2.87 & 0.16 \\
\hline 16 & 3.13 & 0.053 & 3.10 & 0.16 \\
\hline 17 & 3.06 & 0.054 & 2.73 & 0.15 \\
\hline 18 & 3.14 & 0.052 & 2.67 & 0.14 \\
\hline Total & 53.93 & 1.000 & 50.95 & 2.83 \\
\hline $\begin{array}{l}\text { Weighted } \\
\text { average }\end{array}$ & \multicolumn{4}{|c|}{2.83} \\
\hline $\begin{array}{l}\text { Customer } \\
\text { satisfaction } \\
\text { Index } \\
\end{array}$ & \multicolumn{4}{|c|}{0,566} \\
\hline
\end{tabular}

Selanjutnya setelah diketahui masing-masing weighted score dari tiap kriteria dilanjutkan dengan menghitung weighted median total (WMT) dengan cara menjumlahkan semua weighted score yang hasilnya sebesar 0,566. sebelumnya diketahui pada kuisioner yang disebar peneliti menggunakan skala maksimum sebesar 5, sehingga customer satisfaction index (CSI) :

$$
\begin{gathered}
C S I=\frac{\text { WMT }}{\text { Skala Maksimum }} \\
\text { CSI }=\frac{2,83}{5}=0,566 \text { atau } 56 \%
\end{gathered}
$$




\section{Importance Performance Analysis (IPA)}

Pengukuran IPA dijabarkan kedalam diagram kartesius yang tersaji pada tabel Gambar tersebut menunjukan adanya sumbu X dan Y. Sumbu X merupakan nilai rataan tingkat kinerja, berdasarkan hasil perhitungan sumbu $X$ memiliki nilai sebesar 0,566. sumbu Y merupakan nilai rataan kepentingan berdasarkan perhitungan . Untuk mengetahui secara jelas penempatan dari 18 kriteria pelayanan kualitas jasa yang telah dianalisa tersebut, maka 18 kriteria pelayanan tersebut akan dikelompokan menjadi empat kuadran dapat dilihat pada gambar berikut

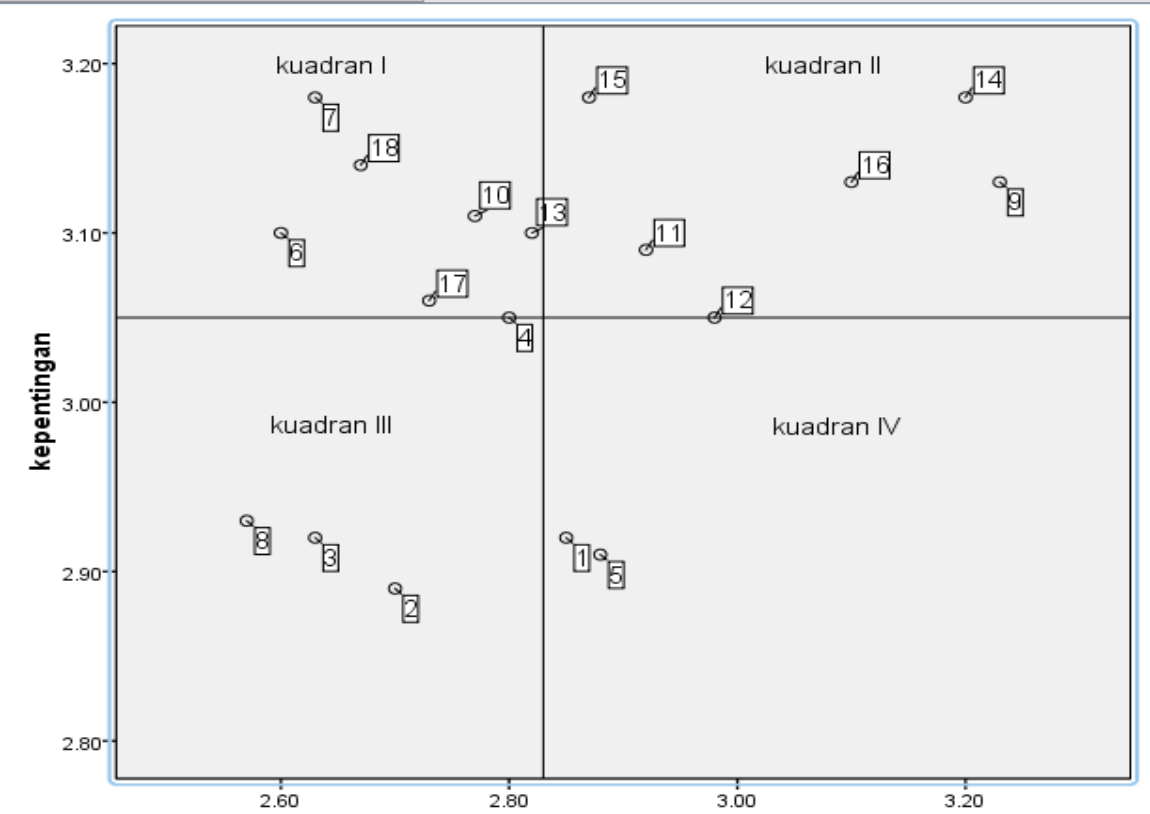

Gambar 2. Diagram Kartesius

\section{Regresi Linier Berganda}

Tabel 3. Regresi Linier Berganda

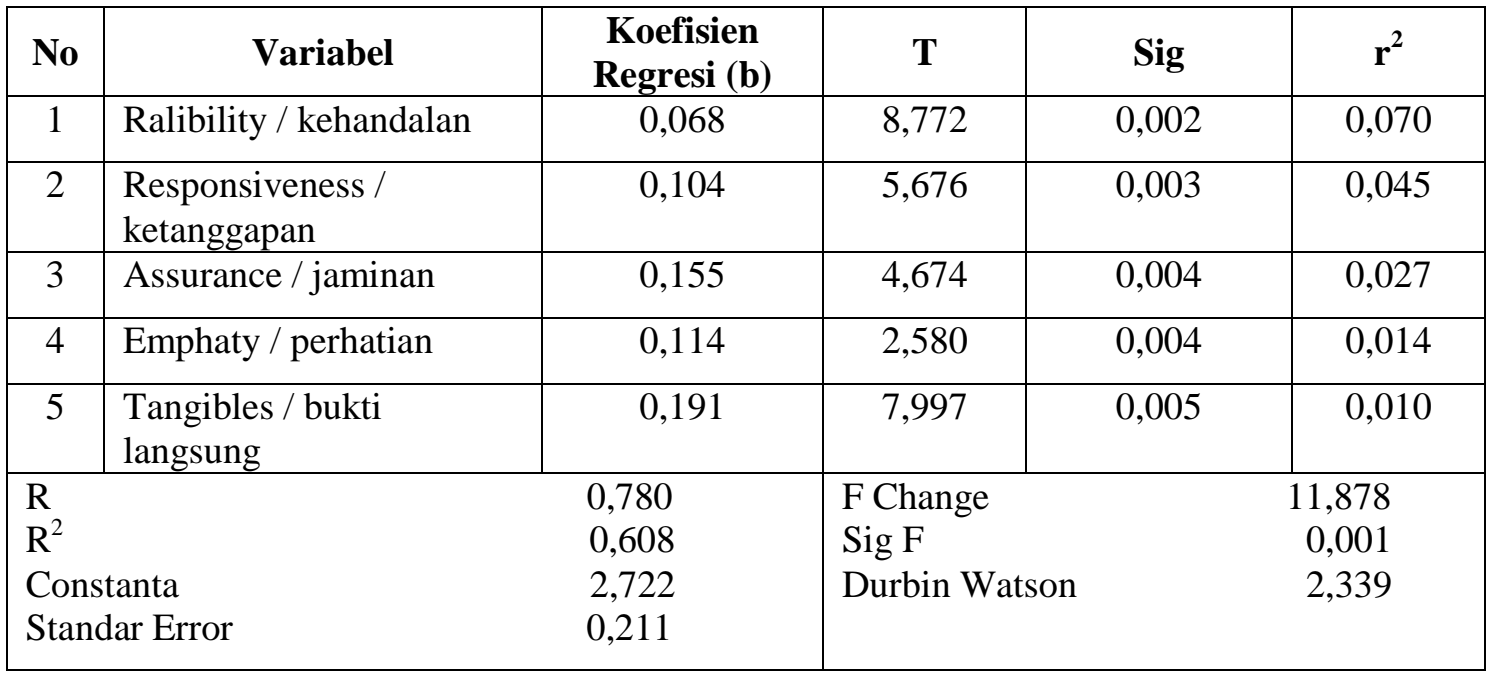




\section{KESIMPULAN}

1. Berdasarkan hasil perhitungan dari customer Satisfaction Index (CSI) diketahui bahwa nilai CSI sebesar 0,566 atau 56\% nilai tersebut berada pada interval 0,51 - 0,65 yang berarti konsumen merasa "cukup puas" terhadap kinerja apa yang telah dilakukan oleh pihak penyedia jasa pengiriman yaitu PT. Gaido Cito Ekakurindo Cabang Surabaya ini.

2. Berdasarkan hasil Importance Performance Analysis (IPA) maka dapatkan bahwa terdapat 7 kriteria yang dianggap penting dalam menentukan tingkat kepuasan konsumen terhadap pelayanan PT. Gaido Cito Ekakurindo dianggap kurang memuaskan bagi konsumen. Ketujuh kriteria itu adalah : kemampuan menjaga piket yang dikirim dalam keadaan utuh (kriteria 4), petugas menunjukkan sikap ramah dan dan siap melayani (kriteria 6), kemampuan mendengarkan ketika pelanggan meminta pelayanan (kriteria 7), petugas selalu menunjukkan sikap percaya diri dan siap melayani pelanggan (kriteria 10), keramahan karyawan PT. Gaido Cito Ekakurindo (kriteria 13), penampilan karyawan PT. Gaido Cito Ekakurindo (kriteria 17), kebersihan dan keterampilan PT. Gaido Cito Ekakurindo (kriteria 18). Dari hasil diatas menunjukkan bahwa nilai-nilai yang sangat penting dan ini dapat diperkuat dengan adanya hasil regresi nilai yang sangat berpengaruh yang perlu diperbaiki dan dari hasil regresi menunjukkan bahwa variabel tangible sangat berpengaruh yaitu atribut 17 (penampilan kayawan PT. Gaido Cito Ekakurindo) dan 18 (kebersihan dan keterampilan PT. Gaido Cito Ekakurindo).

3. Dari hasil penelitian pengaruh variable-variabel terhadap kepuasan konsumen secara parsial, maka dapat disampulkan bahwa variabel tangibles/kehandalan $\mathrm{t}_{\text {hitung }}(8,772)>$ dari $t_{\text {tabel }}(2,005)$ maka Ho ditolak, maka variabel tangibles/kehandalan berpengaruh terhadap kepuasan konsumen, sedangkan responsiveness / ketanggapan memiliki nilai $t_{\text {hitung }}(5,676)>$ dari $t_{\text {tabel }}(2,005)$ maka Ho ditolak, berarti nilai variabel responsiveness / ketanggapan berpengaruh terhadap kepuasan konsumen. assurance / jaminan memiliki nilai $t_{\text {hitung }}(4,674)>$ dari $t_{\text {tabel }}(2,005)$ maka Ho diterima maka variabel assurance / jaminan berpengaruh terhadap kepuasan konsumen, sedangkan untuk variabel emphaty / perhatian memiliki nilai $t_{\text {hitung }}(2,580)>$ dari $_{\text {tabel }}(2,005)$ maka Ho ditolak maka variabel emphaty / perhatian ini berpengaruh terhadap kepuasan konsumen. Dan sedangakan untuk variabel tangibles / bukti langsung memiliki nilai $t_{\text {hitung }}(7,997)>$ dari $_{\text {tabel }}(2,005)$ maka Ho ditolak, maka variabel ini tidak berpengaruh terhadap kepuasan konsumen.

\section{DAFTAR PESTAKA}

[1] Aryani Dwi dan Rosinta Febriana. 2010. Pengaruh Kualitas Layanan Terhadap Kepuasan Pelanggan dalam Membentuk Loyalitas Pelanggan. Depok: Program Studi Ilmu Administrasi Departemen FISIP, Universitas Indonesia.

[2] Donoriyanto Sukma Dwi. Analisis Kualitas Pelayanan Jasa Pengiriman Barang Dengan Metode Servqual dan QFD di PT. Apas. Surabaya: Teknik Industri FTIUPN Jatim.

[3] Dwiwinarsih Rina. Analisis Tingkat Kepuasan Konsumen Terhadap Pelayanan Bakmi Aisy Di Depok. Bandung: Fakultas Ekonomi, Universitas Gunadarma.

[4] Edy Wibowo Agung. Aplikasi Praktis SPSS Dalam Penelitian

[5] Irawan, H. 2003. Prinsip Kepuasan Pelanggan. Jakarta: Elex Media Komputindo.

[6] Kotler, Philip. 1997. Manajemen Pemasaran, Analisi, Perencanaan, Implementasi dan Control Jilid I. Jakarta: Edisi Kesembilan. PT Prenhallindo Jakarta.

[7] Marianah Dewi. Kontribusi Kepuasan Kerja dan Kualitas Jasa Terhadap Kepuasan Nasabah. Bandung: Universitas Gunadarma.

[8] Marliana, Sonya dan Dharmastiti, Rini. 2008. Integrasi SERVQUAL dan QFD Untuk meningkatkan Kualitas Layanan Angkutan Massa Trans Jogja. Jogjakarta: Jurusan Teknik Mesin dan Industri, Fakultas, Teknik, UGM.

[9] Parasuraman, A. V. A. Zeithaml dan L.L. Berry, 1998, SERVQUAL : A Multiplane Item Scale For Measuring Consumers Preceptions Of Service Quality,Journal Of Retailing, Vol.64, No. 1. 
[10] Saidani, Basrah dan Arifin, Samsul. 2012, Pengaruh Kualitas Produk dan Kualitas Layanan Terhadap Kepuasan Konsumen dan Minat Beli Pada Ranch Market. Jakarta: Fakultas Ekonomi Universitas Negeri Jakarta.

[11] Singarimbun, M., \& Effendi, S. 1989. Metode Penelitian Survai. Jakarta: LP3ES Sriwidodo Untung. Pengaruh Dimensi Kualitas Pelayanan Jasa Terhadap Kepuasan Nasabah.

[12] Subanidja Steph. 2007. Pengaruh Dimensi Kualitas Jasa pelayanan Terhadap Tingkat Kepuasan. Jakarta: Program Pascasarjana Perbanas.

[13] Suharsimi Arikunto, 2006, Prosedur Penelitian, Edisi Revisi VI, Rineka Cipta, Jakarta.

[14] Supranto, J. 1997. Pengukuran Tingkat Kepuasan Pelanggan untuk menaikkan Pangsa Pasar. Rineka Cipta, Jakarta.

[15] Tjiptono, F . 2004. Prinsip-prinsip Total Quality Service . PT. Andi Ofset. Yogyakarta

[16] Tjiptono, F., Chandra, G. 2005. Service, Quality dan Satisfaction. Jogjakarta: Penerbit Andi Yogyakarta. 